УдК 347.457.1

\title{
O. I. Виговський
}

\section{ПРОСПЕКТ ЦІННИХ ПАПЕРІВ ЯК ІНСТРУМЕНТ РОЗКРИТТЯ ІНФОРМАЦІЇ НА РИНКУ ЦІННИХ ПАПЕРІВ}

Постановка проблеми. Одним із пріоритетних завдань правового регулювання ринку цінних паперів $€$ забезпечення інформованості інвесторів про емітентів цінних паперів, що підлягають публічному розміщенню. Важливим напрямом реалізації цього завдання $є$ контроль за розкриттям емітентом інформації про свою компанію, іiі фінансово-економічне становище, а також про запланований випуск цінних паперів у спеціальному документі, який під час публічного розміщення цінних паперів підлягає обнародуванню до початку розміщення. Інвестор має бути забезпечений усіма умовами для прийняття інформованого інвестиційного рішення про придбання цінних паперів, і кращим засобом розкриття інформації про емітента та про емісію вважається проспект - свого роду «паспорт» випуску цінних паперів, а також запрошення інвесторів до участі у капіталі товариства. Як зазначав свого часу I. Тарасов, проспект має значення запрошення з боку засновників взяти участь у підприємстві, а тому обов'язково має містити всі дані, на підставі яких передплатник міг би скласти правильне та повне уявлення про характер підприємства, ступінь його солідності та доходності [1, с. 222].

Законодавства більшості держав світу встановлюють жорсткі вимоги щодо змісту та порядку розкриття інформації, що міститься у проспекті, а також запроваджують сувору відповідальність за надання недостовірної інформації в тексті проспекту. Так, в США розділ 10 Закону «Про цінні папери» 1933 року передбачає необхідність підготовки проспекту цінних паперів, а також відомостей, які підлягають включенню до проспекту. Відповідно до п. 15 ч. 1 ст. 1 Закону України «Про цінні папери та фондовий ринок» від 23.02.2006 року проспект цінних паперів - це документ, який оформлюється під час здійснення публічної пропозиції цінних паперів та містить інформацію відповідно до вимог, визначених законом. Як зазначається у ч. 1 ст. 5 Директиви 2003/71/ЄС Європейського Парламенту та Ради від 4 листопада 2003 р. про проспект, що підлягає публікації під час публічної пропозиції цінних паперів чи їх допуску до торгів 
(далі - «Директива ЄС про проспект»), цей документ містить всю інформацію, яка необхідна для надання інвесторам можливості зважено оцінити активи та пасиви, фінансове становище, прибутки та збитки, перспективи діяльності емітента та будь-якого гаранта, а також права, що посвідчуються цінними паперами. Дана Директива у ст. 3(1) вимагає, щоб державиучасниці не дозволяли здійснення будь-якої пропозиції цінних паперів широкому загалу в межах їх територій без попередньої публікації проспекту.

Аналіз останніх публікацій та досліджень. В українській правовій доктрині теоретичні питання, пов'язані з використанням проспекту цінних паперів для розкриття інформації на фондовому ринку, не були об'єктом належної уваги з боку науковців. Окремі питання щодо проспектів порушувалися у роботах щодо цінних паперів та їх емісії, зокрема, О.Ю. Синенко [2], А.С. Рогова [3], Г.Н. Шевченко [4], а також досліджувалися у спеціальних роботах М. Бондаревської [5], Д. Вавуліна [6], Н.А. Вербицької [7], Є.В. Галкової [9] та інших.

Разом з тим на доктринальному рівні залишаються невирішеними деякі питання теоретичного та прикладного характеру, що стосуються цього важливого інструменту розкриття інформації на фондовому ринку, зокрема, питання про правову природу проспекту цінних паперів та відповідальність за недостовірну чи оманливу інформацію в проспекті. Крім того, за умов пожвавлення процесів інтеграції України у європейський фінансовий та економічний простір та необхідності наближення українського законодавства про цінні папери до європейських стандартів особливої актуальності набуває вивчення результатів гармонізаційних процесів у сфері правового регулювання випуску та розміщення цінних паперів в країнах ЄС.

Метою даної статті $€$ аналіз питання про правову природу проспекту цінних паперів, зокрема, можливості його кваліфікації як оферти цінних паперів від емітента, яку має акцептувати інвестор, дослідження підстав відповідальності за вміщення недостовірної інформації у проспекті, а також вивчення уніфікаційних та гармонізаційних процесів на теренах $€ C$ в контексті запровадження «принципу взаємного визнання» відносно проспектів цінних паперів, зареєстрованих в одній із держав ЄС.

Викладення основних результатів. Публічність проспекту цінних паперів забезпечується вимогою щодо його реєстрації та публікації у спосіб, визначений національним регулятором фондового ринку. Невиконання цієї вимоги зазвичай тягне за собою застосування кримінальних санкцій, а порушення вимог щодо змісту такого документу зумовлює виникнення суворої адміністративної, цивільної та кримінальної відповідальності. Реалізація таких вимог забезпечує прозорість на фондовому ринку, зменшує ризики шахрайства з боку недобросовісних емітентів, підвищує довіру суспільства до фінансового сектору, захищає інвесторів від прийняття помилкових інвестиційних рішень та знижує ризики втрат внаслідок потенційних банкрутств емітентів. Крім того, належне розкриття інформації емітентом забезпечує встановлення адекватної ринкової ціни на цінні папери, що пропонуються до продажу. 
Аналіз законодавств іноземних держав дозволяє виділити наступні критерії, які визначають необхідність підготовки та публікації проспекту цінних паперів:

1) спосіб розміщення цінних паперів (проспекти зазвичай необхідно розкривати широкому загалу у випадку публічного розміщення);

2) кількість потенційних набувачів цінних паперів (наприклад, коли цінні папери пропонуються більш ніж 100 особам);

3) обсяг емісії, тобто сумарної номінальної вартості всіх цінних паперів запланованого випуску;

4) характер потенційних інвесторів (так, якщо цінні папери будуть розміщуватися виключно серед інституційних інвесторів, для яких інвестиційна діяльність являє собою професійну діяльність і які повною мірою можуть усвідомлювати ризики, пов'язані з таким інвестуванням, вимоги щодо проспекту можуть бути більш ліберальними або взагалі відсутніми).

Іншими словами, підготовка та публікація проспекту стають обов'язковими, коли емітент планує залучати кошти від значного або заздалегідь необмеженого кола інвесторів, які не $є$ в даний момент учасниками компанії, а отже, не мають належного рівня інформованості про емітента та про цінні папери.

В правовій доктрині дискусійним є питання щодо правової природи проспекту цінних паперів. Чи можна вважати проспект офертою укласти договір купівлі-продажу цінних паперів з емітентом? Чи виступає в такому випадку емітент в якості оферента, а інвестор - в якості акцептанта оферти (при цьому формою вираження акцепту буде заявка на придбання цінних паперів)?

На наш погляд, зіставлення класичного поняття оферти у договірному праві та юридичних характеристик проспекту дає всі підстави стверджувати, що проспект не може розглядатися як оферта придбавати цінні папери. Як зазначає А.Ю. Синенко, проспект емісії може розглядатися як приклад оферти лише за дотримання таких умов: (1) емітент повинен вжити активних дій щодо направлення проспекту потенційним набувачам або зробити його доступним для них іншим способом; (2) проспект емісії містить пряму вказівку на те, що він є офертою [2, с. 65]. Водночас на практиці під час здійснення публічного розміщення цінних паперів проспект не адресується будь-яким конкретним особам, його цільова аудиторія є максимально широкою, ознайомитися з ним може будь-який потенційний інвестор, зокрема, той, про існування якого емітент навіть не здогадується. Безумовно, емітент ніколи не позначає даний документ як оферту. На нашу думку, публікація проспекту з юридичної точки зору є нічим іншим, як рекламою випуску цінних паперів. Публікація зареєстрованого регулятором проспекту під час публічного розміщення є способом здійснення маркетингу цінних паперів, що вимагається на нормативному рівні і який не замінюють будь-які інші маркетингові заходи (презентації («роад-шоу»), публікації в пресі, оголошення в соціальних мережах тощо). Юридична особа рекламує свої цінні папери шляхом розкриття норматив- 
но передбаченої інформації про себе та свій випуск та укладає договори купівлі-продажу з тим, хто відгукнеться на цю рекламу та зажадає придбати визначену кількість цінних паперів. Саме такий інвестор робитиме оферту щодо придбання цінних паперів. Іншими словами, пропозиція необмеженому колу осіб набувати у власність цінні папери не зумовлює виникнення зобов'язання емітента укладати правочини з цим необмеженим колом осіб: емітент, не будучи зв'язаним умовами оферти, вправі відмовити майбутньому інвестору в укладенні договору купівлі-продажу.

Відповідальність за нерозкриття інформації у проспекті, неповне розкриття або включення недостовірної інформації вважається абсолютною, тобто вона виникає у емітента незалежно від його обізнаності з реальними фактами. Будь-яке зняття з себе такої відповідальності за допомогою спеціальних застережень в тексті проспекту є неможливим. Специфічним $є$ i коло осіб, що несуть відповідальність за зміст проспекту. Окрім директорів (членів виконавчого органу) емітента, до таких осіб зазвичай включаються аудитори (вони несуть відповідальність в частині, що стосується фінансової звітності емітента), андерайтери, інколи - юристи та інші експерти, мажоритарні акціонери. Характерною особливістю є настання відповідальності навіть за відсутності вини (так, відповідно до абз. 2 ч. 5 ст. 36 Закону України «Про цінні папери та фондовий ринок» відповідальність за достовірність відомостей, наведених у документах, що подаються для затвердження проспекту, несе особа, яка оформила проспект).

Якщо оманлива чи недостовірна інформація була свідомо включена до проспекту, це $є$ підставою для виникнення кримінальної відповідальності та цивільної відповідальності за нанесені збитки. Однак в правовій доктрині не до кінця розробленим $є$ питання щодо змісту поняття недостовірної інформації у проспекті цінних паперів. На наш погляд, таке поняття не повинно зводитися винятково до переліку недостовірних фактів. Так, будьяка заява емітента про наміри (наприклад, щодо напрямів використання коштів, отриманих від емісії цінних паперів, майбутніх програм модернізації виробництва, дивідендної політики тощо) є недостовірною інформацією, якщо емітент насправді не мав такого наміру на момент оформлення проспекту. Будь-які прогнози щодо майбутніх показників економічного зростання чи підвищення рентабельності виробництва можуть також кваліфікуватися як недостовірні, якщо емітент сам не вірив у їх реальність (хоча такий факт буде складно довести) або на момент оформлення проспекту існували факти, які очевидно заперечували його здійсненність. Разом з тим цілком реалістичний прогноз, який не відбувся через політичні або макроекономічні фактори, не повинен бути підставою для притягнення емітента до відповідальності за недостовірну інформацію.

Одним 3 ключових аспектів системи правового регулювання випуску та обігу цінних паперів в країнах $€ C €$ «принцип взаємного визнання» (англ. "mutual recognition principle"), зафіксований в ряді нормативних документів. Так, відповідно до ч. 1 ст. 17 Директиви $Є C$ про проспект, проспект, схвалений у державі його походження, буде вважатися законною 
підставою для проведення публічного розміщення чи допуску до торгів у будь-якій іншій державі-учасниці, де буде здійснюватися така діяльність, за умови повідомлення компетентного органу такої держави. Відповідне повідомлення має надаватися компетентним органом держави реєстрації проспекту на вимогу емітента чи особи, відповідальної за підготовку проспекту, протягом трьох робочих днів після отримання відповідного запиту, або протягом одного робочого дня з моменту схвалення проспекту, якщо запит був поданий одночасно з проектом проспекту, шляхом надання компетентному органу держави місця здійснення розміщення чи проведення торгів свідоцтва про схвалення проспекту, який підтверджує, що проспект був складений у відповідності до вимог даної Директиви (ч. 1 ст. 18). Спеціальні положення передбачені ст. 20 цієї Директиви відносно емітентів, зареєстрованих в третіх державах. Компетентний орган державиучасниці може схвалити проспект, складений відповідно до законодавства третьої держави, за умови, що: (а) проспект був складений відповідно до міжнародних стандартів, включаючи стандарти розкриття інформації IOSCO; (б) вимоги до інформації, що міститься в проспекті, включаючи інформацію фінансового характеру, еквівалентні вимогам, встановленим даною Директивою.

Слід зазначити, що принцип взаємного визнання в тому вигляді, як його відтворено в текстах нормативного інструментарію $Є$, не варто розглядати як спосіб вирішення колізійних питань, оскільки дійсність проспекту та інформаційних меморандумів іноземного походження у будьякій державі-учасниці «зумовлена ані застосуванням класичних колізійних норм, ані добровільним наданням іноземному праву переважної юридичної сили перед внутрішньодержавним правом...» [9, с. 155]. Нормативні акти ЄC лише визначають державу походження емітента як компетентну юрисдикцію для схвалення проспекту, і акти його державних органів винятково з огляду на принцип взаємного визнання, закріплений наднаціональним законодавством ЄС, отримують визнання в будь-якій іншій державі-учасниці. Іноземне право як таке в даному випадку не застосовується; рішенню іноземного державного органу про схвалення проспекту надається юридична сила на території іншої держави винятково на основі факту ідентичності базових стандартів, що існують для подібних документів в усіх державах-учасницях, які імплементували відповідні Директиви ЄС. Визначення компетентного правопорядку з усіх інших питань транскордонного розміщення цінних паперів продовжує здійснюватися на підставі колізійних норм національних законодавств держав - членів ЄС.

В умовах розвитку глобального фінансового ринку гостро відчувається потреба у прискоренні уніфікаційних процесів на регіональному та універсальному рівнях. Міжнародні договори та угоди, які встановлюють однакові вимоги до порядку випуску і розміщення цінних паперів, розкриття інформації емітентами та іншими учасниками ринку цінних паперів, умови та форми захисту інтересів інвесторів в процесі розміщення цінних паперів емітентами-нерезидентами, слід розглядати в якості основних інструмен- 
тів, що забезпечують процес уніфікації норм у даній сфері на універсальному та регіональному рівнях.

Найбільш істотні кроки у цьому напряму були здійснені на регіональному рівні шляхом прийняття базового нормативного інструментарію $Є C$ 3 його наступною трансформацією в національні законодавства європейських держав. У країнах ЄС діяльність на ринку цінних паперів традиційно розглядається в рамках свободи надання послуг і свободи руху капіталу, які визначають основну спрямованість правового регулювання в цій сфері. Систему правового регулювання випуску та обігу цінних паперів в рамках $€ C$ утворюють як спеціальні нормативні акти, що регулюють окремі аспекти у сфері обігу цінних паперів (наприклад, Директива 2003 / 6 ЄС Європейського Парламенту і Ради від 28 січня 2003 р. про інсайдерські правочини та маніпулювання ринком (зловживання на ринку)), так і комплексні нормативні акти, що належать зазвичай до сфери регулювання надання фінансових послуг та інвестиційної діяльності, які містять приписи щодо тих або інших аспектів діяльності на ринку цінних паперів.

На нормативному рівні була реалізована ідея так званого «єдиного європейського паспорта» для емітентів, що дозволяє їм залучати фінансові кошти шляхом випуску і розміщення цінних паперів на всій території $Є C$ без необхідності реєстрації випуску і проспекту в кожній державі такого розміщення. Основними результатами гармонізаційних процесів в рамках ЄC у галузі правового регулювання розміщення цінних паперів стала уніфікація порядку розкриття емітентами інформації відповідно до загальновизнаних міжнародних стандартів, запровадження спрощеної процедури розміщення цінних паперів емітентів, які вже допущені до торгів на організованих ринках держав - членів ЄС, практична реалізація концепції «єдиного паспорта» емітента.

\section{Висновки.}

1. Публікація проспекту з юридичної точки зору є нічим іншим, як рекламою випуску цінних паперів. Публікація зареєстрованого регулятором проспекту під час публічного розміщення є способом здійснення маркетингу цінних паперів. Пропозиція необмеженому колу осіб набувати у власність цінні папери не зумовлює виникнення зобов'язання емітента укладати правочини 3 цим необмеженим колом осіб: емітент, не будучи зв'язаним умовами оферти, вправі відмовити майбутньому інвестору в укладенні договору купівлі-продажу.

2. 3 огляду на «принцип взаємного визнання», закріплений наднаціональним законодавством $\in C$, акти державних органів держави походження емітента щодо схвалення проспекту чи для надання дозволів на здійснення діяльності на ринку цінних паперів отримують визнання в будь-якій іншій державі - учасниці ЄС. Реалізація принципу «єдиного європейського паспорта» для емітентів дозволяє їм залучати фінансові кошти шляхом випуску і розміщення цінних паперів на всій території ЄС без необхідності реєстрації випуску і проспекту в кожній державі такого розміщення. 


\section{Література}

1. Тарасов И.Т. Учение об акционерных компаниях. Москва : Статут, 2000.

2. Синенко А.Ю. Эмиссия корпоративных ценных бумаг: правовое регулирование, теория и практика. Москва : Статут, 2002.

3. Шевченко Г.Н. Эмиссионные ценные бумаги: понятие, эмиссия, обращение. Москва : Статут, 2006.

4. Рогов А.С. Гражданско-правовое регулирование эмиссии акций. Автореф. дис. ... канд. юрид. наук. Екатеринбург, 2002.

5. Бондаревская $M$. Проспект ценных бумаг: особенности гражданско-правовой квалификации. Хозяйство и право. 2014. №7. С. 89-98.

6. Вавулин Д. Новый порядок эмиссии эмиссионных ценных бумаг и регистрации проспектов ценных бумаг. Право и экономика. 2007. № 9. С. 44-59.

7. Вербицкая Н.А. Проспект ценных бумаг как предмет злоупотребления при эмиссии ценных бумаг. Актуальные проблемы правоведения. Сборник наунных статей. Красноярск : РУМЦ ЮО, 2005. С. 145-154.

8. Галкова Е.В. Соотношение принципа сохранности капитала акционерного общества и ответственности эмитента за проспект ценных бумаг. Закон. 2015. №11. С. 114-131.

9. Wegen G., Lindemann C. The Law Applicable to Public Offerings in Continental Europe / The Law of Cross-Border Securities Transactions, by H. van Houtte (ed.). London: Sweet \& Maxwell, 1999. P. 153-172.

\section{Ан о т а ц і я}

Виговський O. I. Проспект цінних паперів як інструмент розкриття інформації на фондовому ринку. - Стаття.

Стаття присвячена висвітленню правових питань використання проспекту як засобу забезпечення розкриття інформації на ринку цінних паперів. У статті аналізується правова природа проспекту цінних паперів, питання відповідальності емітента та інших осіб за недостовірну інформацію у проспекті, а також результати гармонізаційних процесів у сфері правового регулювання випусків та розміщення цінних паперів в рамках $€ \mathcal{~}$, в тому числі в контексті запровадження «принципу взаємного визнання» щодо зареєстрованих проспектів цінних паперів як ключового принципу забезпечення формування єдиного європейського фондового ринку.

Ключові слова: цінні папери, проспект, емітент, інвестор, «принцип взаємного визнання».

\section{А н нот а ция}

Выговский $A$. И. Проспект ценных бумаг как инструмент раскрытия информации на фондовом рынке. - Статья.

Статья посвящена освещению правовых вопросов использования проспекта как средства обеспечения раскрытия информации на рынке ценных бумаг. В статье анализируется правовая природа проспекта ценных бумаг, вопросы ответственности эмитента и других лиц за недостоверную информацию в проспекте, а также результаты гармонизационных процессов в сфере правового регулирования выпусков и размещения ценных бумаг в рамках ЕС, в том числе в контексте внедрения «принципа взаимного признания» относительно зарегистрированных проспектов ценных бумаг как ключевого принципа обеспечения формирования единого европейского фондового рынка.

Ключевые слова: ценные бумаги, проспект, эмитент, инвестор, «принцип взаимного признания». 


\section{S u m m a r y}

Vygovskyy O.I. Securities prospectus as an instrument of disclosure at stock market. Article.

This article highlights legal issues of using securities prospectus as a document ensuring disclosure at the securities market. The author of the article analyzes legal nature of securities prospectus, misrepresentation liability of an issuer and other persons for false information contained in the prospectus, as well as the results of harmonization processes in legal regulation of issue and placement of securities within EU, in particular, in the context of introduction of mutual recognition principle regarding registered securities prospectuses as key principle underlying the formation of single European stock market.

Key words: securities, prospectus, issuer, investor, mutual recognition principle. 